\title{
Pengaruh Pelimpahan Wewenang Terhadap Kualitas Pelayanan di Kantor Kecamatan Cileunyi
}

\author{
${ }^{1}$ Usep Muhammad Abdul Qohar, ${ }^{2}$ Asep Hidayat
}

${ }^{1}$ UIN Sunan Gunung Djati Bandung; Indonesia; qoharrain@gmail.com

${ }^{2}$ UIN Sunan Gunung Djati Bandung; Indonesia; dr.asephi62@gmail.com

\begin{abstract}
The implementation of effective and efficient service quality in the Sub-district office environment illustrates the implementation of delegation of authority given by the Regent to the District Head. Where the District Head carries out some of the functions the Regent gives to provide services to the community in the sub-district environment. As regulated by the Regent of Bandung Regency No. 60 of 2011 concerning the delegation of authority for some of the Regent's affairs to the District Head. But in reality on the ground, there are some problems regarding services that have not yet been implemented which have resulted in ineffective implementation of services to the community. The purpose of this study is to determine how much influence the authority, responsibility and accountability regarding the transfer of authority in the District of Cileunyi. This study uses a theory from Hasibuan which consists of three authority delegation variables, namely authority, responsibility, accountability. As for service quality using the theories of Zeithaml, Parasuraman, Leonard quoted by Hardiyansyah. The sample used was 30 employees in the Cileunyi District office. The research method used is a quantitative method with an associative approach that aims to determine the relationship of one or more variables, namely the influence of delegation of authority to the quality of service in the district of Cileunyi. The results of this study indicate that the influence of delegation of authority (authority, responsibility, accountability) has an influence on the quality of service in the Cileunyi District office of 0.555 or $55.5 \%$, then it is included in the "High" influence criteria. For the remaining $100 \%-55.5 \%=44.5 \%$ influenced by other variables not examined by researchers.
\end{abstract}

Keywords: Service Quality, Decentralization, Accountability and Responsibility

\section{Pendahuluan}

Adanya kebijakan otonomi daerah sangat berpengaruh terhadap pelayanan kepada masyarakat dan mendorong perubahan pemerintahan, baik secara struktural fungsional maupun kultur dalam penyelenggaraan pemerintahan daerah. Dalam menjalankan otonomi daerah, kepala daerah tidak akan dapat melaksanakan tugas dan wewenangnya tanpa ada bantuan dari unsur perangkat daerah yang lebih rendah yaitu kecamatan dan kelurahan. Sebagai mana menurut (Anggara, 2014) kebijakan publik adalah keputusan yang mengikat bagi orang banyak pada tataran stategis atau bersipat garis besar yang di buat oleh pemegang otoritas publik. Sedangkan fokus utama kebijakan publik di negara modern adalah pelayanan publik, yaitu segala sesuatu yang bisa dilakukan oleh negara untuk mempertahankan atau meningkatkan kualitas kehidupan orang banyak.

Sejalan dengan adanya Peraturan Bupati Bandung Nomor 60 Tahun 2011 Tentang Pelimpahan Wewenang dari Bupati kepada Camat, maka dalam melaksanakan sebagian tugas yang telah di limpahkan oleh Bupati. Oleh karen itu, kecamatan memiliki peran penting untuk membantu tugas dan wewenang kepala daerah dalam mewujudkan terlaksananya urusan wajib maupun pilihan dalam kerangkang otonomi daerah. Hal ini berdampak pada tugas dan fungsi kecamatan yang di berikan wewenang untuk melaksanakan pelayanan terhadap masyarakat. Serta dengan adanya perluasan pelimpahan wewenang terhadap kecamatan bisa adanya peningkatan kualitas pelayanan kepada masyarakat. Menurut (Handoko, 2009) bahwa delegasi adalah pelimpahan wewenang dan tanggung jawab formal kepada orang lain untuk 
melaksanakan kegiatan tertentu. Delegasi wewenang adalah proses dimana para manajer mengalokasikan wewenang ke bawah kepada orang-orang yang melapor kepadanya. Sedangkan wewenang (Authority) adalah hak untuk melakukan sesuatu atau memerintah orang lain untuk melakukan atau tidak melakukan sesuatu agar tercapai tujuan tertentu. Selanjutnya Menurut (Hasibuan, 2016) Terdapat tiga unsur dimensi pelimpahan wewenang, yaitu:

1. Wewenang

Wewenang adalah kekuasaan yang sah dan legal yang dimiliki seseorang untuk memerintah orang lain, berbuat atau tidak berbuat sesuatu; authority merupakan dasar hukum yang sah dan legal untuk dapat mengerjakan suatu pekerjaan.

2. Tanggung Jawab

Tanggung jawab adalah keharusan untuk melakukan semua kewajiban/tugas-tugas yang dibebankan kepadanya sebagai akibat dari wewenang yang di terima atau dimilikinya.

3. Akuntabilitas (accountability)

Tanggung jawab ini timbul karena adanya hubungan antara atasan (delegator) dan bawahan (delegate), dimana atasan mendelegasikan wewenang (pekerjaan) kepada bawahan untuk di kerjakan. Delegate harus benar-benar mempertanggung jawabkan wewenang yang di terimanya kepada delegator. Jika tidak sewaktu-waktu wewenang itu dapat ditarik kembali delegator dari delegate-nya.

Kecamatan Cileunyi yang merupakan bagian dari kecamatan di daerah Kabupaten Bandung telah melaksanakan pelayanan sesuai dengan peraturan Bupati yang telah di berikan, namun dalam pelaksanaan pelimpahan wewenang dari Bupati kepada Camat tidak di imbangi dengan sumberdaya pegawai yang memadai, salah satunya dengan tingkat jenjang pendidikan yang masih rendah. Selain itu masih kurangnya komitmen pegawai dalam membantu camat menjalankan wewenang yang di limpahkan oleh Bupati. Berikut ini tabel jumlah pegawai menurut jenjang pendidikan:

Tabel 1

Jumlah Pegawai Berdasarkan Pendidikan

\begin{tabular}{|c|c|c|c|c|c|c|c|}
\hline No & Uraian & SLTP & SLTA & Diploma III & Strata 1 & Strata 2 & Jumlah \\
\hline 1 & Camat & & & & 1 & & 1 \\
\hline \multirow[t]{4}{*}{2} & Sekretariat & & & & & & \\
\hline & Sekretaris Kecamatan & & & & & 1 & 1 \\
\hline & $\begin{array}{l}\text { Subag Program dan } \\
\text { Keuangan }\end{array}$ & & 2 & & 3 & & 5 \\
\hline & $\begin{array}{l}\text { Subag Umum dan } \\
\text { Kepegawaian }\end{array}$ & & 4 & 1 & 1 & & 6 \\
\hline 3 & Kasi Pemerintahan & & 3 & & 4 & 1 & 8 \\
\hline 4 & $\begin{array}{l}\text { Kasi Keamanan dan } \\
\text { Ketertiban Umum }\end{array}$ & & 3 & & 2 & & 5 \\
\hline 5 & Kasi Pemberdayaan & & 1 & & 1 & & 4 \\
\hline 6 & Kasi Pembangunan & & & & 1 & & 1 \\
\hline 7 & $\begin{array}{l}\text { Kasi Sosial dan } \\
\text { Kebudayaan }\end{array}$ & & & & & 1 & 1 \\
\hline & Jumlah & & 13 & 1 & 13 & 3 & 30 \\
\hline
\end{tabular}

Sumber: Laporan Akuntabilitas Kinerja Instansi Pemerintah Kecamatan Cileunyi, 2018 
Dari data tersebut dapat dilihat bahwa pegawai di Kantor Kecamatan Cileunyi berjumlah 30 meliputi Pegawai Negeri Sipil (PNS), pegawai NON-PNS, SATPOL PP. Untuk tingkat pendidikan di dominasi oleh lulusan SLTA dan Strata 1 sebanyak 26 orang, dimana untuk lulusan Strata 1 di dominasi oleh pegawai NON-PNS dan SATPOL PP. Di tambah dengan adanya beberapa pegawai yang pensiun dan mutasi jabatan membuat kekosongan dalam struktur jabatan di Kecamatan Cileunyi.

Berkaitan dengan peraturan Bupati No 60 Tahun 2011 di harapkan adanya percepatan kualitas pelayanan terhadap masyarakat. Sebagai mana yang di kemukakan oleh Daviddow dan Uttal (1989) yang di kutip oleh (Hardiyansyah, 2011 : 35) kualitas merupakan usaha apa saja yang digunakan untuk mempertinggi kepuasan pelanggan (whatever enhances customer satisfaction). Sedangikan Lonsdale (1994) dalam buku (Deddy, Mulyadi 2016) berpendapat bahwa pelayanan publik ialah segala sesuatu yang telah di sediakan oleh pemerintah atau swasta baik barang ataupun jasa, karena pada dasarnya masyarakat tidak dapat memenuhi kebutuhannya sendiri, kecuali secara kolektif dalam rangka mermenuhi kesejahtraan seluruh masyarakat. Sedangkan menurut Ahmad dkk, yang di kutip oleh (Zaenal, Muhibudin 2016) Pelayanan publik (public service) adalah pemberian oleh pemerintah terhadap masyarakat baik berupa penggunaan fasilitas umum, jasa maupun non jasa. Dimana penerima pelayanan meliputi individu, kelompok atau badan hukum yang memilikin hak dan kewajiban dalam suatu pelayanan publik. Menurut Zeithaml, Parasuraman, dan Leonard (1990) di kutip oleh (Zaenal, Muhibudin 2016) ada beberapa indikator pelayanan yaitu: 1. Tangibel-Bukti Langsung, 2. Reliability-Kehandalan, 3. Responsiviness-Ketanggapan, 4. Assurance-Jaminan, 5. EmpathyEmpati.

Penelitian ini bertujuan untuk mengetahui pengaruh pelimpahan wewenang terhadap kualitas pelayanan di kantor Kecamatan Cileunyi. Dengan adanya pelimpahan ini di harapakan adanya peningkatan kualitas pelayanan terhadapa masyarakat dengan efektif dan efisien. Penelitian ini telah banyak di lakukan sebelumnya, namun kebanyakan lebih menekankan pada salah satu dimensi pelimpahan wewenang. Seperti (Rifly, 2009) melakukan penelitian tentang "Pengaruh pendelegasian wewenang dan komitmen terhadap prestasi kerja karyawan pada bagian sumber daya manusia PT. Perkebunan Nusantara IV (Persero) Medan". Sedangkan dalam penelitian ini membahas tentang tiga dimensi yang kemukakan oleh (Hasibuan, 2016).

\section{Metode Penelitian}

Pada penelitian ini penulis menggunakan pendekatan penelitian asosiatif dengan pendekatan kuantitatif. Sebagai mana menurut (Sugiyono, 2014) Penelitian asosiatif merupakan suatu penelitian yang bertujuan untuk mengetahui hubungan antara dua variabel atau lebih. Metode ini digunakan karena untuk peneliti akan menyajikan data berbentuk angka atau data kualitatif yang di angkakan. Disebut penelitian asosiatif karena peneliti menggunakan dua variable dalam penelitian ini, yaitu implementasi kebijakan (X) sebagain variabel indevenden (bebas), dan kualitas pelayanan publik (Y) sebagai variabel dependen (terikat).

Teknik pengumpulan data yang di gunakan dalam penelitian ini menggunakan kuesioner yang di sebarkan kepada seluruh pegawai kecamatan cileunyi yang berjumlah 30 orang dengan jumlah pertanyaan sebanyak 30 . Observasi yang di lakukan di kantor kecamatan cileunyi serta dokumentasi yaitu laporan akuntabilitas kinerja instansi pemerintah (LAKIP). Dalam penentuan sampel menggunakan sampel jenuh karena jumlah polasi kurang dari 30 orang. Selanjutnya peneliti dalam pengolahan data responden menggunakan penskalaan/ penentuan nilai responden dengan tipe skala ordinal yang dapat di urutkan dalam tingkat urutan (rank order) dalam hubungan dengan jumlah atribut yang di miliki, serta menggunakan skala 
Likert. (Ulber, 2012:229) dalam penelitian sosial, skala Likert banyak digunakan terutama mengukur sikap, pendapat, atau presepsi seseorang tentang dirinya atau kelompooknya atau sekelompok orang yanng berhubungan dengan suatu hal.

\section{Hasil dan Pembahasan}

Berikut ini penulis sajikan hasil penelitian serta pembahasan pengaruh pelimpahan wewenang terhadap kualitas pelayanan di kantor kecamatan Cileunyi:

\section{Pengaruh Wewenang Terhadap Kualitas Pelayanan}

Untuk menjawab rumusan masalah tentang pengaruh wewenang terhadap kualitas pelayanan di kantor kecamatan Cileunyi, di peroleh nilai koefisien korelasi sebesar 0,659. Maka sebagai mana pendapat (Sugiyono, 2014) bahwa nilai tersebut termasuk dalam hubungan yang "kuat" antara wewenang terhadap kualitas pelayanan di kantor kecamatan Cileunyi. Selanjutnya untuk hipotesis penelitian tentang pengaruh wewenang terhadap kualitas pelayanan di lakukan pengujian uji t untuk mengetahui adanya atau tidaknya pengaruh antara tanggung jawab terhadap kualitas pelayanan. Maka penulis membandingkan $t$ hitung dengan $t$

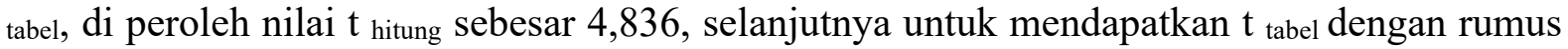
$(\alpha / 2 ; n-k-1)$ dimana $\alpha$ merupakan derajar kebebasan $=5 \%, \mathrm{n}$ adalah jumlah sampel, dan $\mathrm{k}$ merupakan jumlah variabel independen, 1 nilai konstan. Di dapatkan nilai t tabel sebesar 2,056, dapat di simpulkan bahwa t hitung $>\mathrm{t}$ tabel $(4,836>2,056)$ maka hipotesis Ho di tolak Ha di terima, dengan kata lain hipotesis yang penulis ajukan yaitu terdapat hubungan antara pengaruh wewenang terhadap kualitas pelayanan di kantor kecamatan Cileunyi.

\section{Pengaruh Tanggung Jawab Terhadap Kualitas Pelayanan}

Untuk menjawab rumusan masalah tentang pengaruh tanggung jawab terhadap kualitas pelayanan di kantor kecamatan Cileunyi, di peroleh nilai koefisien korelasi sebesar 0,554. Maka sebagai mana pendapat (Sugiyono, 2014) bahwa nilai tersebut termasuk dalam hubungan yang "sedang". Dengan demikian korelasi pengaruh tanggung jawab terhadap kualitas pelayanan di kantor kecamatan Cileunyi memiliki korelasi hubungan yang sedang. Selanjutnya untuk hipotesis penelitian tentang pengaruh tanggung jawab terhadap kualitas pelayanan di lakukan pengujian uji t untuk mengetahui adanya atau tidaknya pengaruh antara tanggung jawab terhadap kualitas pelayanan. Maka penulis membandingkan $t$ hitung dengan $t$ tabel, di peroleh nilai $t$ hitung sebesar 3,693, selanjutnya untuk mendapatkan $t_{\text {tabel }}$ dengan rumus $(\alpha / 2 ; n-$ $\mathrm{k}-1$ ) dimana $\alpha$ merupakan derajar kebebasan $=5 \%$, $\mathrm{n}$ adalah jumlah sampel, dan $\mathrm{k}$ merupakan jumlah variabel independen, 1 nilai konstan. Di dapatkan nilai t tabel sebesar 2,056, dapat di simpulkan bahwa t hitung $>\mathrm{t}$ tabel $(4,683>2,056)$ maka hipotesis Ho di tolak Ha di terima, dengan kata lain hipotesis yang penulis ajukan yaitu terdapat hubungan antara pengaruh tanggung jawab terhadap kualitas pelayanan di kantor kecamatan Cileunyi.

\section{Pengaruh Akuntabilitas Terhadap Kualitas Pelayanan}

Untuk menjawab rumusan masalah tentang pengaruh akuntabilitas terhadap kualitas pelayanan di kantor kecamatan Cileunyi, di peroleh nilai koefisien korelasi sebesar 0,681. Maka sebagai mana pendapat (Sugiyono, 2014) bahwa nilai tersebut termasuk dalam hubungan yang "kuat" antara wewenang terhadap kualitas pelayanan di kantor kecamatan Cileunyi. Selanjutnya untuk hipotesis penelitian tentang pengaruh akuntabilitas terhadap kualitas pelayanan di lakukan pengujian uji $t$ untuk mengetahui adanya atau tidaknya pengaruh antara tanggung jawab terhadap kualitas pelayanan. Maka penulis membandingkan $t$ hitung dengan $t$ tabel, di peroleh nilai $t$ hitung sebesar 3,473, selanjutnya untuk mendapatkan $t$ tabel dengan rumus $(\alpha / 2 ; n-k-1)$ dimana $\alpha$ merupakan derajar kebebasan $=5 \%, \mathrm{n}$ adalah jumlah sampel, dan $\mathrm{k}$ 
merupakan jumlah variabel independen, 1 nilai konstan. Di dapatkan nilai $t$ tabel sebesar 2,056, dapat di simpulkan bahwa $t_{\text {hitung }}>\mathrm{t}_{\text {tabel }}(3,473>2,056)$ maka hipotesis Ho di tolak Ha di terima, dengan kata lain hipotesis yang penulis ajukan yaitu terdapat hubungan antara pengaruh akuntabilitas terhadap kualitas pelayanan di kantor kecamatan Cileunyi.

\section{Pengaruh Pelimpahan Wewenang Terhadap Kualitas Pelayanan}

Untuk menjawab rumusan masalah tentang pengaruh pelimpahan wewenang terhadap kualitas pelayanan di kantor kecamatan Cileunyi dengan menggunakan aplikasi SPSS 20 di peroleh nilai koefisien determinasi dari dimensi wewenang, tanggung jawab, akuntabilitas $\mathrm{R}$ squernya sebesar 0,555. Sebagai mana pendapat (Ulber, 2012) Koefisien determinasi dinyatakan dalam persen (\%) sehingga harus dikalikan dengan $100 \%$. Tepatnya jika koefisien korelasi antara variabel $\mathrm{X}$ dan $\mathrm{Y}$ adalah 1.00 , koefisien determinasi adalah $1^{2}$ atau $1 \times 100 \%$. Maka di peroleh 0,555 atau 55,5\% artinya 55,5\% kualitas pelayanan di pengaruhi oleh pelimpahan wewenang.

Selanjutnya untuk mengetahui pengaruh pelimpahan wewenang secara serentak, penulis melakukan pengujian uji $\mathrm{f}$ (simultan) dengan membandingkan $\mathrm{f}$ hitung dengan $\mathrm{f}$ tabel. Dari pengujian tersebut di peroleh nilai f hitung sebesar 10,823, sedangkan untuk memperoleh nilai $\mathrm{f}$ tabel menggunakan rumus tingkat keyakinan $95 \% \alpha=5 \% . \mathrm{F}=(\mathrm{k} ; \mathrm{n}-\mathrm{k})$ di peroleh nilai $\mathrm{f}$ tabel sebesar 2,96. Dengan demikian f hitung $>\mathrm{f}$ tabel $(10,823>2,96)$ maka dapat di artikan bahwa maka hipotesis Ho di tolak Ha di terima, dengan kata lain hipotesis yang penulis ajukan yaitu terdapat hubungan yang signifikan antara pengaruh pelimpahan wewenang terhadap kualitas pelayanan di kantor kecamatan Cileunyi

\section{Simpulan}

Berdasarkan penelitian yang telah di lakukan mengenai "pengaruh pelimpahan wewenang terhadap kualitas pelayanan di kantor Kecamatan Cileunyi" dapat di ambil kesimpulan sebagai berikut:

1) Pengaruh wewenang terhadap kualitas pelayanan berdasarkan hasil pengujian regresi secara parsial mendapatkan nilai t tabel sebesar 4,683, maka dapat di simpulkan bahwa $(4,683>2,056)$. Ho di tolak dengan peluang 0,05 atau $5 \%$ dan $\mathrm{Ha}$ di terima. Artinya terdapat pengaruh secara parsial antara variabel wewenang terhadap kualitas pelayanan di kantor Kecamatan Cileunyi.

2) Pengaruh tanggung jawab terhadap kualitas pelayanan berdasarkan hasil pengujian regresi secara parsial mendapatkan nilai t tabel sebesar 3,518, maka dapat di simpulkan bahwa $(3,518>2,056)$. Ho di tolak dengan peluang 0,05 atau $5 \%$ dan $\mathrm{Ha}$ di terima. Artinya terdapat pengaruh secara parsial antara variabel tanggung jawab terhadap kualitas pelayanan di kantor Kecamatan Cileunyi.

3) Pengaruh akuntabilitas terhadap kualitas pelayanan berdasarkan hasil pengujian regresi secara parsial mendapatkan nilai t tabel sebesar 4,927, maka dapat di simpulkan bahwa $(4,927>2,056)$. Ho di tolak dengan peluang 0,05 atau $5 \%$ dan $\mathrm{Ha}$ di terima. Artinya terdapat pengaruh secara parsial antara variabel akuntabilitas terhadap kualitas pelayanan di kantor Kecamatan Cileunyi.

4) Pengaruh wewenang, tanggung jawab dan akuntabilitas Dari data hasil penghitungan koefisien regresi secara bersama-sama, di dapatkan skor f sebesar 10,823. Sedangkan untuk mencari nilai f tabel menggunakan rumus tingkat keyakinan 95\% $\alpha=5 \% . \mathrm{F}=(\mathrm{k} ; \mathrm{n}-\mathrm{k})=(3 ; 30-3)=3 ; 27=2,96$. Maka didaptkan nilai f hitung 2,96 yang menunjukan bahwa f hitung $>$ f tabel yaitu $10,823>2,96$, selanjutnya nilai sig 
$<0,05$. Dari data tersebut dapat di simpulkan bahwa Ho di tolak dan Ha di terima. Artinya dari hasil pengujian secara simultan variabel wewenang X1, tanggung jawab $\mathrm{X} 2$ dan akuntabilitas X3 terhadap variabel kualitas pelayanan Y. Terjadi pengaruh yang signifikan secara simultan antara wewenang, tanggung jawab, akuntabilitas terhadap kualitas pelayanan di kantor Kecamatan Cileunyi.

\section{Referensi}

Deddy, M. (2016). Studi Kebijakan Publik dan Pelayanan Publik (M. Deddy (ed.)). Alfabeta. Handoko. (2009). Manajemen (Handoko (ed.); Kedua). BPFE-Yogyakarta.

Hardiyansyah. (2011). Kualitas Pelayanan Publik (Hardiyansyah (ed.)). Gava Media.

Hasibuan, M. S. P. (2016). Manajemen: Dasar, Pengertian, dan Masalah (M. S. P. Hasibuan (ed.); tujuh). PT Bumi Aksara.

Sahya, A. (2014). Kebijakan Publik (Anggara Sahya (ed.)). CV Pustaka Media.

Sugiyono. (2014). Metode Penelitian Administrasi (Sugiyono (ed.); 22nd ed.). Alfabeta.

Ulber, S. (2012). Metode Penelitian Sosial (S. Ulber (ed.)). PT Refika Adimata.

Zaenal, M. W. L. (2016). Membangun Kinerja Pelayanan Publik (M. W. L. Zaenal (ed.)). Cv Pustaka Setia. 